\title{
Comments to the article "The political role of the State in Cambridge theories of growth and distribution"
}

\author{
Comentário sobre o artigo "The political role of the State \\ in Cambridge theories of growth and distribution"
}
JOÃO GABRIEL DE ARAUJO OLIVEIRA**** RENATO NOZAKI SUGAHARA $* * *$ JOANILIO RODOLPHO TEIXEIRA ${ }^{\mathrm{x}, \mathrm{x} x}$

\begin{abstract}
RESUMO: Este comentário refuta e corrige as ideias propostas por Charles (2007) sobre as implicações negativas na distribuição de renda, quando impactadas pela expansão do consumo com base em atividades governamentais, em favor das famílias. Nós provamos que as escolhas políticas, para ambos os casos (aumento do consumo ou lucro), impactam positivamente a distribuição e não afetam a essência do resultado da dinâmica e equilíbrio do modelo Kaldor neo-Pasinetti e "Equação de Cambridge". A estabilidade do modelo é garantida aplicando o Teorema de Olech para o caso.

PALAVRAS-CHAVE: Distribuição; pós-keynesiano; governo; estabilidade.
\end{abstract}

ABSTRACT: This comment came to refute and correct the idea of Charles (2007) about the negatively implications in the income distribution when the government expand the consumption in favour to households. We prove that the political choice, to both cases (increasing consumption or increasing profit), impact positively the income distribution and does not affect the essential nature of the Kaldor neo-Pasinetti dynamic equilibrium results and the "Cambridge Equation". The stability of the model is guarantee by applying the Olech's Theorem to the case.

KEYWORDS: Distribution; post-keynesian; government; stability.

JEL Classification: O15; E12; G38.

\footnotetext{
* Doutorando em Economia pela Universidade de Brasília - FACE-UnB, Brasília/DF, Brasil. E-mail: joaogabrielaraujooliveira@gmail.com. Orcid: https://orcid.org/0000-0002-2130-8659.

** Membro da Associação Keynesiana Brasileira.

*** Professor Adjunto da Universidade Estadual de Londrina - UEL, Londrina/PR, Brasil. E-mail: renatonozakisugahara@yahoo.com.br. Orcid: https://orcid.org/0000-0002-2167-0367.

x Professor emérito da Universidade de Brasília - UnB, Brasília/DF, Brasil. E-mail: joanilioteixeira@hotmail. com. Orcid: https://orcid.org/0000-0001-6527-1782.

xx Fellow of the World Academy of Art and Science. Submitted: 17/March/2020; Approved: 20/May/2020. Note of the editor: We tried to contact the author Sebastien Charles for a reply but with no success.
} 


\section{INTRODUCTION}

Kaldor (1966) create the "Kaldor neo-Pasinetti Theorem" as a reply to Pasinetti (1962), showing that in his model it is possible to consider the division between firms and households. His model presents two sides. It shows how the existence of the financial system implicates on the income distribution. The first side indicates the traditional profit rate and the second the valuation ratio of the firms in the financial market. The significant point of this theorem is that the profit rate affects negatively the valuation ratio, and the existence of financial assets leads to a reduction of the profit rate. Panico (1997) which introduces the concept of capital gains to analyse how the existence of firms can impact the level of income and the implication of its distribution in the case of government activities. It is interesting to note that all the Political Orientations of the above extensions were assumed to be exogenous.

The relevance of the "Cambridge Equation" persists nowadays. Romero (2019) combines the Kaldorian approach with Schumpeter to present a new cumulative growth model. Pacheco-Lópes and Thirlwall (2014) verify the association among manufacturing output growth, export growth as well as between export growth and GDP growth in 89 developing countries. Bernardo, Stockhammer, and Martínez (2016) shows the reinterpretation of the Tobin's q from the Kaldor neo-Pasinetti perspective, which can be linked with the present extension. George (2018) made a positive analysis of modern capitalism from the Pasinetti perspective to consider the implication of investors' decisions in a long-run perspective. Taylor, Foley, and Rezai (2019) presented an empirical analysis to the U.S. economy in a postKeynesian perspective based on Goodwin, Kaldor and Pasinetti's theories in the steady-state. They conclude that the GDP and capital stock, in the long-run, grow approximately $2 \%$ in such a country, which is close to the real data. They also indicate the necessity to consider another feature towards a more realistic analysis.

Here, we intend to focus on the Kaldorian approach, presenting the correct version of the Charles (2007). In this case, we are dealing with a more realistic context in comparison with most of the literature. Our paper is divided in four sections. The first one is this introduction. The second presents the mathematical mistakes of Charles (2007), our correct version and its analytical interpretations. The third presents the stability condition of the model to the case of increase consumption. In the end of our paper presents the concluding remarks, with some interpretations of the model linked with the pro-poor and pro-rich theories.

\section{RECONSIDERING THE EXTENSION OF CHARLES (2007) ABOUT THE POLITICAL ORIENTATION}

Wondering about this, Charles (2007) elaborated a Kaldorian extension model with Political Orientation which deserves especial attention. Accordingly, section $\mathrm{V}$ of his article starts by differencing the government orientation in two ways. The 
first shows the increasing consumption in favour of households, and the second rising profit favouring to firms. His assumptions are:

$$
\begin{aligned}
& Y=W+P \\
& S=S_{h}+S_{f} \\
& S_{h}=S_{h}\left(1-t_{w}\right) W \\
& S_{f}=S_{f}\left(1-t_{p}\right) P \\
& x I=S_{h}\left(1-t_{w}\right) W-c G \\
& I+G e=S_{f}\left(1-t_{p}\right) P+x I \\
& I+G e=S_{f}\left(1-t_{p}\right) P+s_{h}\left(1-t_{w}\right) W-c G \\
& G e=\alpha(\bar{C}-C), \quad \bar{C}>C, \quad \text { been } \quad 0 \leq \alpha \leq 1 \\
& G e \alpha(\bar{P}-P), \quad \bar{P}>P
\end{aligned}
$$

Charles consider a consumption function in order to develop his extension. However, the post-Keynesian defines the income as a sum of the wages and profits, but this is also equal to the sum of the consumption, investment and government expenditures, as well as a Keynesian function, in a close economy. Thus:

$$
\mathrm{Y}=\mathrm{C}+\mathrm{I}+\mathrm{Ge}
$$

Mathematical manipulations in Appendix 2 indicate that Charles (2007) committed some mathematical and logical mistakes. Our first contribution corrects his results in relation to the consumption incentives. His model disappeared with the difference between the valuation ratio and the share of investments financed by the financial market $\left(v_{r}-x\right) W$. The actual results are given by (5) and (6):

$$
\begin{aligned}
& r=\frac{g_{n}[(1+\alpha)-x]+\alpha \bar{c}+\frac{\alpha}{v}}{s_{f}\left(1-t_{p}\right)} \\
& v_{r}=\frac{1}{\operatorname{cg}_{n}}\left\{\frac{s_{h}\left(1-t_{w}\right)}{v}-\operatorname{xg}_{n}(1-c)-s_{h}\left(1-t_{w}\right)\left[\frac{g_{n}[(1+\alpha)-x]+\alpha \bar{c}+\frac{\alpha}{v}}{s_{f}\left(1-t_{p}\right)}\right]\right\} \\
& \text { where } \bar{C}=\frac{\bar{C}}{K} .
\end{aligned}
$$


With the same manipulations, but considering (ix) we have the equations favouring profits (firms), as expressed by (7) and (8). These two results are expressed correctly by Charles (2007):

$$
\begin{aligned}
& \mathrm{r}=\frac{\alpha \overline{\mathrm{r}}+\mathrm{g}_{\mathrm{n}}(1-\mathrm{x})}{\mathrm{s}_{\mathrm{f}}\left(1-\mathrm{t}_{\mathrm{p}}\right)+\alpha} \\
& \mathrm{v}_{\mathrm{r}}=\frac{1}{\operatorname{cg}_{\mathrm{n}}}\left\{\frac{\mathrm{sh}_{\mathrm{h}}}{\mathrm{v}}\left(1-\mathrm{t}_{\mathrm{w}}\right)-\mathrm{g}_{\mathrm{n}}(1-\mathrm{c}) \mathrm{x}-\mathrm{s}_{\mathrm{h}}\left(1-\mathrm{t}_{\mathrm{w}}\right)\left[\frac{\alpha \overline{\mathrm{r}}+\mathrm{g}_{\mathrm{n}}(1-\mathrm{x})}{\mathrm{s}_{\mathrm{f}}\left(1-\mathrm{t}_{\mathrm{p}}\right)+\alpha}\right]\right\}
\end{aligned}
$$

Equations (5) and (6) show us that the government expenditure to incentive the households will affect the income distribution positively: $\frac{\partial r}{\partial \bar{c}}=\frac{\alpha}{s_{f}\left(1-t_{p}\right)}>0$. And negatively the valuation ratio $\frac{\partial r}{\partial v_{r}}=-\frac{s_{h}\left(1-t_{w}\right) \alpha}{c g_{n} s_{f}\left(1-t_{p}\right)}<0$, which is a different result in comparison to Charles (2007). In this vein, the government can choose to incentive workers without any damage to the economy. This kind of policies can represent the propoor theory, intending to justify the relation between the politicians and the society. On the other hand, the equation (7) and (8) indicate that government expenditures tend to increase profit and the profit ratio will be bigger, favouring the firms, being a pro-rich theory as is pointed out by Gillespie (1978).

\section{THE STABILITY CONDITION TO THE MODEL TO THE CASE OF INCENTIVE TO CONSUMPTION}

In this section, we apply the Olech's Theorem ${ }^{1}$ to analyse the stability of the model to the case of incentive to consumption. From the equation $(\mathrm{d})^{2}$ we obtain:

$$
\begin{aligned}
& \frac{d r}{d t}=E\left(r, v_{r}\right)=\delta\left[g_{n}-\frac{s_{h}}{v}\right]=\delta\left\{g_{n}+\alpha\left(\bar{c}-\frac{1}{v}+g_{n}\right)-s_{f}\left(1-t_{p}\right) r-\right. \\
& \left.\frac{s_{h}}{v}\left(1-t_{w}\right)+s_{h}\left(1-t_{w}\right) r+c\left(v_{r}-x\right) g_{n}\right\}, \delta>0
\end{aligned}
$$

Considering that the net demand for placements (xi) is equal to the worker's savings less the consumption from capital gains and the supply of new securities issued by the corporation (xii), as in Davidson (1968) and Araújo (1995), we have:

$$
\begin{aligned}
& D_{p}=s_{h}\left(1-t_{w}\right) W-c G \\
& S_{p}=x I\left(\frac{K}{K}\right)=x_{n} K
\end{aligned}
$$

Following the conventional IS-LM stability analyses, we postulate the equilibrium adjustment between $r$ and $v_{r}$, represented by the excess demand function below:

\footnotetext{
${ }^{1}$ See Garcia (1972).

2 See Appendix 2.
} 


$$
\begin{aligned}
& \quad \frac{d v_{r}}{d t}=E\left(r, v_{r}\right)=\varphi\left[\frac{D_{p}}{K}-\frac{S_{p}}{K}\right]=\varphi\left[\frac{S_{h}}{v}\left(1-t_{w}\right)-s_{h}\left(1-t_{w}\right) r\right. \\
& -\operatorname{cg}_{n} v_{r}+\operatorname{cxg}_{n}-x_{r}
\end{aligned}
$$

being $\varphi>0$

From (9) and (10) we can analyse the stability condition, considering the first term of the Taylor expansion. From this, we are allowed to determinate the matrix system, where we present the Jacobian Matrix:

$$
J\left[E\left(r, v_{r}\right)\right]=\left[\begin{array}{cc}
-\delta\left[\mathrm{s}_{\mathrm{f}}\left(1-\mathrm{t}_{\mathrm{p}}\right)\right] & \delta \mathrm{cg}_{\mathrm{n}} \\
-\varphi \mathrm{s}_{\mathrm{h}}\left(1-\mathrm{t}_{\mathrm{w}}\right) & -\varphi c g_{\mathrm{n}}
\end{array}\right]
$$

Applying the Olech's Theorem in (11), we have all the tools to analyse the stability in a Matrix $2 \times 2$. This is a necessary and sufficient condition if the trace is negative and the determinant is positive. Thus:

$$
\begin{aligned}
& \operatorname{Tr}(J)=-\delta\left[\mathrm{s}_{\mathrm{f}}\left(1-\mathrm{t}_{\mathrm{p}}\right)\right]-\varphi \mathrm{cg}_{\mathrm{n}}<0 \\
& |J|=\delta \varphi \operatorname{cg}_{\mathrm{n}}\left[\mathrm{s}_{\mathrm{f}}\left(1-\mathrm{t}_{\mathrm{p}}\right)\right]+\varphi \mathrm{s}_{\mathrm{h}}\left(1-\mathrm{t}_{\mathrm{w}}\right) \delta \operatorname{cg}_{\mathrm{n}}>0
\end{aligned}
$$

These results show us that, with all the assumptions assumed above, the model is stable as required. Furthermore, we conclude that our extension satisfied the stability conditions. It is easy to show that, same occurs to the incentives to profit.

\section{CONCLUDING REMARKS}

The present paper contains three important issues. The first, presented in the second section is that kipping Charles' (2007) hypotheses and correcting his mathematical mistakes, it was shown that the incentives to consumption is positively related with the profit ratio and negative with the valuation ratio. These results are close to the pro-poor theory when the government activities are used to compress the income difference between capitalists and workers (here as firms and households). On the other hand, the incentives can increase only the profit, representing a pro-rich theory. Both theories are presented by Gillespie (1978). In this vein, the real question is: "what incentive will be made?" The answer stays in the hands of the government and will be exogenously to the model. However, this approach can be used by legislators to develop proposals in the income distribution field, analysing the effects to the economy. Our result corrects the "logical sleep" committed by Charles. In the third section we prove that the model is stable for the case of incen- 
tive to consumption. From this, we are able to conclude that in the long-run our extension will always converge to equilibrium in steady-state.

\section{REFERENCES}

Araújo, Jorge Thompson (1995) “Kaldor's Neo-Pasinetti Model and Cambridge Theory of Distribution", The Manchester School, 63(3): 311-317.

Bernardo, Javier Lópes; Stockhammer, Engelbert and Martínez, Felix Lópes. 2016. “A post Keynesian Theory for Tobin's q in a Stock-Flow Consistent Framework" Journal of Post-Keynesian Economics 39(2): 256-285.

Bertola, Giuseppe (2000) "Macroeconomics of Distribution and Growth", in: Anthony B. Atkinson and François Bourguignon (eds), Handbook of Income Distribution, Paris: Elsevier: 577-40.

Charles, Sebastien (2007) "The Political Role of the State in Cambridge Theories of Growth and Distribution", Revista de Economia Política, 27(4): 567-574.

Davidson, Paul (1968) "The Demand and Supply of Securities and Economic Growth and its Implications for the Kaldor-Pasinetti versus Samuelson-Modigliani Controvers", American Economic Review, 57(2): 252-269.

Garcia, Gillian. 1972. “Olech's Theorem and the Dynamic Stability of Theories of Rate Interest” Journal of Economic Theory 4(3): 541-544.

George, Donald A. R. 2018. "Economic Growth with Institutional Saving and Investments" Review of Political Economy 30(1): 28-40.

Kaldor, Nicholas (1956) “Alternative Theories of Distribution”, The Review of Economic Studies, 23(2): 83-100.

Kaldor, Nicholas (1966) "Marginal Productivity and Macro-Economic Theories of Distribution: Comment on Samuelson and Modigliani”, The Review of Economic Studies, 33(4): 309-319.

Lavoie, Marc (2014) "Theory of the Firms", in: Post-Keynesian Economics: New Foundations, Cheltenham: Edward Elgar: 123-181.

Pacheco-Lópes, Penélope and Thirlwall, Anthony Philip. 2014. "A New Interpretation of Kaldor's First Growth Law for Open Developing Economies." Review of Keynesian Economics 2(3): 384-398.

Panico, Claudio (1997.) "Government Deficits in post-Keynesian Theories of Growth and Distribution”, Contributions to Political Economy, 19(1): 61-86.

Pasinetti, Luigi (1962) "Rate of Profit and Income Distribution to the Rate of Economic Growth", The Review of Economic Studies, 29(4): 267-279.

Romero, João Prates. 2019. “A Kaldor-Schumpeter model of Cumulative Growth” Cambridge Journal of Economics: 1-25.

Taylor, Lance; Foley, Duncan K. and Rezai, Armon. 2019. "Demand Drives Growth all the Way: Goodwin, Kaldor, Pasinetti and the Steady State." Cambridge Journal of Economics 43(5): 1333 1352.

\section{APPENDIX 1: Notations}

$\alpha$ speed adjustment of government policy

c marginal propensity to consume of the capital gain/loses

$\bar{c}$ consumption increased by the Political Orientation in capital terms

C general consumption

$\overline{\mathrm{C}}$ general consumption increased by the Political Orientation 
E Excess Demand

$\mathrm{g}_{\mathrm{n}}$ natural growth rate

$\mathrm{G}$ capital gains/loses

$\mathrm{G}_{\mathrm{e}}$ government expending with Political Orientation

i nominal interest rate

I domestic investment

J Jacobian Matrix

IJl Determinant of the Jacobian Matrix

$\mathrm{K}$ capital stock

$\mathrm{N}$ share of the firm in the financial market

$\mathrm{p}$ price level

$\mathrm{P}$ profit

$\overline{\mathrm{P}}$ profit increased by the Political Orientation

$r$ profit rate

$\overline{\mathrm{r}}$ profit increased by the Political Orientation in capital terms

$S$ saving

$\mathrm{s}_{\mathrm{f}}$ marginal propensity to save of the firms

$S_{\mathrm{f}}$ firms savings

$\mathrm{s}_{\mathrm{h}}$ marginal propensity to save of the households

$S_{h}$ households saving

$t$ time

$\mathrm{T}$ amount tax

$\mathrm{T}_{\mathrm{r}}$ (J) Trace of the Jacobian Matrix

$t_{p}$ marginal tribute to the profit

$t_{w}$ marginal tribute to the wages

$\mathrm{v}$ technology

$\mathrm{v}_{\mathrm{r}}$ valuation ratio of the share in financial markets

$\mathrm{x}$ share of the investment financiered by the existence of the financial market

$\mathrm{W}$ wages amount

$\mathrm{Y}$ income

APPENDIX 2: The correct equation of incentive to consumption for Charles (2007) considering the following assumptions:

$$
\mathrm{G}_{\mathrm{e}}=\alpha(\overline{\mathrm{C}}-\mathrm{C}) ; \quad \mathrm{Y}=\mathrm{C}+\mathrm{I}+\mathrm{G}_{\mathrm{e}}
$$

Substituting (b) in (a) we have:

$$
\mathrm{G}_{\mathrm{e}}=\alpha(\overline{\mathrm{C}}-\mathrm{Y}+\mathrm{I})
$$


Considering the (xiv) and substituting (c):

$\mathrm{I}+\alpha(\overline{\mathrm{C}}-\mathrm{Y}+\mathrm{I})=\mathrm{s}_{f}\left(1-\mathrm{t}_{\mathrm{p}}\right) \mathrm{P}+\mathrm{s}_{\mathrm{h}}\left(1-\mathrm{t}_{\mathrm{w}}\right) \mathrm{Y}-\mathrm{s}_{\mathrm{h}}\left(1-\mathrm{t}_{\mathrm{w}}\right) \mathrm{P}-\mathrm{c}\left(\mathrm{v}_{\mathrm{r}}-\mathrm{x}\right)$

Dividing the equation per K:

$g_{n}+\alpha\left(\bar{c}-\frac{1}{v}+g_{n}\right)=s_{f}\left(1-t_{p}\right) r+\frac{s_{h}}{v}\left(1-t_{w}\right)-s_{h}\left(1-t_{w}\right) r-c\left(v_{r}-x\right) g_{n}$

Isolating $\frac{\mathrm{s}_{\mathrm{h}}}{\mathrm{V}}$ :

$\frac{s_{h}}{v}=\frac{1}{\left(1-t_{w}\right)}\left\{g_{n}\left[(1+\alpha)+c\left(v_{r}-x\right)\right]-r\left[s_{f}\left(1-t_{p}\right)-s_{h}\left(1-t_{w}\right)\right]+\alpha\left(\bar{c}-\frac{1}{v}\right)\right\}$

Now considering (e) equal to $(\mathrm{f})$ :

$$
\begin{aligned}
& \frac{1}{\left(1-t_{w}\right)}\left[x g+c\left(v_{r}-x\right) g_{n}+s_{h}\left(1-t_{w}\right) r\right]=\frac{1}{\left(1-t_{w}\right)} \\
& \left\{g_{n}\left[(1+\alpha)+c\left(v_{r}-x\right)\right]-r\left[s_{f}\left(1-t_{p}\right)-s_{h}\left(1-t_{w}\right)\right]+\alpha\left(\bar{c}-\frac{1}{v}\right)\right\}
\end{aligned}
$$

Isolating $\mathrm{r}$ and we have:

$$
r=\frac{g_{n}[(1+\alpha)-x]+\alpha \bar{c}+\frac{\alpha}{v}}{s_{f}\left(1-t_{p}\right)}
$$

Substituting in $r$ in (e) and manipulating algebraically we can obtain $v_{r}$

$$
\begin{aligned}
& \frac{s_{h}}{v}=\frac{1}{\left(1-t_{w}\right)}\left\{x g+c\left(v_{r}-x\right) g_{n}+s_{h}\left(1-t_{w}\right)\left[\frac{\left.g_{n}[(1+\alpha)-x]+\alpha \bar{c}+{ }_{v}^{\alpha}\right]}{s_{f}\left(1-t_{p}\right)}\right]\right\} \\
& \therefore \frac{s_{h}}{v}-\frac{1}{1-t_{w}} c_{r} g_{n}=\frac{1}{\left(1-t_{w}\right)}\left\{\operatorname{xg}_{n}(1-c)+s_{h}\left(1-t_{w}\right)\left[\frac{g_{n}[(1+\alpha)-x]+\alpha \bar{c}+{ }_{v}^{\alpha}}{s_{f}\left(1-t_{p}\right)}\right]\right\} \\
& v_{r}=\frac{1}{\operatorname{cg}_{n}}\left\{\frac{s_{h}\left(1-t_{w}\right)}{v}-x_{n}(1-c)-s_{h}\left(1-t_{w}\right)\left[\frac{g_{n}[(1+\alpha)-x]+\alpha \bar{c}+{ }_{v}^{\alpha}}{s_{f}\left(1-t_{p}\right)}\right]\right\}
\end{aligned}
$$

